\title{
Determinants of Informal Non- oil Exporting Behaviour in Selected Border Markets in Nigeria
}

\author{
Iweama, Vincent Okwudili ${ }^{1} \quad$ Nkamnebe, A.D ${ }^{2}$ Ramoni, Adewale Suraju ${ }^{1 *}$ \\ Gorondutse, Abdullahi Hassan ${ }^{1}$ \\ 1.Department of Economics and Management Science, \\ Nigeria Police Academy, P.M.B. 3474, Wudil-Kano, Nigeria \\ 2.Professor of Marketing, Department of Marketing, \\ Nnamdi Azikiwe University, Awka, Nigeria
}

\begin{abstract}
The study examined determinants of informal non-oil exporting behaviour in selected border markets in Nigeria. The population of the study was all informal non-oil exporters in the nation's selected border markets while a sample size of 384 was determined using unknown population. Pearson correlation was used to test for discriminant validity with a highest correlation of .501, while factor analysis test of not less than .4 communalities show that no item of the variables need to be eliminated or removed. Two independent variables were used: satisfaction of basic needs and desire to own a business. The dependent variable was the informal non-oil exporting behavior. When the results of the independent variables were considered separately, the only difference to reach a statistical significance using the Bonferroni and Scheffe post-hoc tests is the satisfaction of basic needs, $F(3,25.4)$ $=3.31$; sig. $=.021$; partial eta $=.033$. The two hypotheses formulated for the study were analysed using Kendall's Coefficient of Concordance and they were all statistically significant. This means that the two variables: satisfaction of basic needs and desire to own a business promote involvement in informal non-oil exporting in Nigeria. Recommendations were made that government at all levels should engage in capacity building to educate informal non-oil exporters to graduate to formal economy by registering their businesses and taking advantage of government incentives and should address unemployment.
\end{abstract}

Keywords: Export, Informal Non-Oil Export; Border Markets

DOI: $10.7176 / \mathrm{EJBM} / 12-17-13$

Publication date:June 30th 2020

\section{1, Introduction}

In many developing economies, job creation has mainly taken place in the informal economy where above 60 percent of workers find income opportunities (ILO, 2018). Informal economy creates employment and operators can implement appropriate strategies to exploit opportunities streaming from weakness in trade and economic policies (Chambwer \& Magregor, 2010). On the other hand, a large informal sector can pose problems for policy makers and the overall economic development of their country. Organisation of Economic Cooperation and Development (2004) reported that a large informal sector could indeed deprive government of needed tax revenue which could be reinvested into infrastructure development and other national development priorities. It could influence the development of economic policy objectives by skewing the reliability of data, breed a culture of corruption in public administration and hinder further investment in local (formal) SMEs, which constitute the major part of the private sector in developing countries and are necessary for economic development and growth.

In Nigeria for instance, the size of informal economy is estimated to be as high as $65 \%$ of the total economy; also, one interesting component of the Nigeria's informal market that is receiving research attention, though slowly is the informal non-oil exporting (Iweama, Gorondutse \& Nkamnebe, 2018). Informal non- oil exporting is used in the same sense it was used by the Nigeria Export Promotion Council (NEPC, 2012) as exporting activities that are not registered within the purview of government regulation.

Available survey indicates that a substantial proportion of informal non- oil exports are mainly conducted by individuals, micro, small and medium sized enterprises and consists of small consignments (Agbogun, 2012). Arguably, the informal non- oil export has been thriving in Nigeria, yet scanty research attention has been granted to it. The obvious large size of the informal non-oil export is reflected in the estimated revenue of the sector. For instance NEPC (2013), estimated that above N14 billion informal non oil export took place in 2012 in Dawanau international market corridor in Kano alone. Interestingly, about ninety-three (93) border markets and loading points have been identified across Nigeria (NEPC, 2013, Yuauf, 2011). If an average of N10 billion is assumed for each of 93 border markets and loading points, it can be argued that Nigeria's informal non oil export from land border alone worth's over N930 billion or US \$ 6.2 billion per annum. Iweama (2017) reported a case of US\$12 billion undocumented informal exporting from the nations' seaport, which arguably reduces and skews the reported non-oil exporting in Nigeria. The fiscal implication of these to government and Nigerian economy can only be imagined.

Despite the risks with informal non-oil exporting and better attractions in formalizing their activities through 
Nigerian Export Promotion Council, the operations of informal non-oil exporters have continued to grow in Nigeria. This obvious gap in knowledge has both policy, managerial and knowledge implications, therefore, calling for urgent investigation. Thus, the main objective of this study was to ascertain if satisfaction of basic needs promoted involvement in informal non-oil export in Nigeria and how desperation to own a business has influenced involvement in informal non-oil export in Nigeria. Consequently, the study provided answers to the following research questions:

1. Does satisfaction of basic needs promote involvement in informal non-oil export in Nigeria?

2. To what extent can desperation to own a business influence involvement in informal non-oil export in Nigeria?

These two research questions were converted to two hypotheses and tested accordingly:

$\mathrm{H}_{1}$ : Satisfaction of basic needs promote involvement in informal non-oil export in Nigeria

$\mathrm{H}_{2}$ : Desperation to own a business influence involvement in informal non-oil export in Nigeria

\section{2, REVIEW OF RELATED LITERATURE}

\section{1, Review of Export Sector of the Nigerian Economy}

It has been established in the literature that export is an engine of growth. It increase foreign exchange earnings, improves balance of payment position, creates employments and development of export oriented industries in the manufacturing sector and improves government revenue through taxes, levies and tariffs (Onayemi \& 1shola, 2009). These benefits will eventually transform into better living condition for the nationals of the exporting economy since foreign exchange derived would contribute to meeting their needs for some essential goods and services (Olorunshola,1996). However before these benefits can be fully realized, the structure and direction of these exports must be carefully tailored such that the economy will not depend on only one sector for the supply of needed foreign exchange (Abogan, Akinola \& Baruwa, 2014; Ramat,2011).

In the 1960's, Nigeria's export trade was largely dominated by non-oil products such as groundnuts, palm kernel, palm oil, coca, rubber, coffee, cotton, coal and others. The same pattern continued into the early 1970s, as a matter of fact, cocoa was the dominant export product at that time contributing about $15 \%$ of total exports in 1970 (Osuntogun \& Edordu,2001; Olorunshola,1996). However, oil's dominance of the country's export basket began in 1973/74 and was greatly magnified during the 1980s. The crux of the problem was that while oil export was growing, non-oil export were declining making the dominance much more rapid and pervasive (Pinto,1987). As a result of the setting up of commodity board by the federal government to act as buying agent, this board went about fixing arbitrarily and below market prices, therefore, farmers moved out of the business because they no longer found it profitable. The policy effect was therefore negative development of exports in the agricultural sector. Moreover available data revealed that the manufacturing sub sector of the economy had often been making minimal contribution to export. The reason that can be adduced for this had been neglect for the sector by colonial masters before independence, poor infrastructure, lack of adequate finance, high cost of production and low market penetration due to poor quality control were factors constraining the manufacturing exports (Ajakaiye \& Ayodele,2000; Onayemi \& 1shola,2009; 0jo,1996).

In the 1970s, oil sector experienced price explosion at the global crude oil market, especially in 1973 as a result of crisis in the Middle East. The ultimate effect of this was a massive inflow of foreign exchange. Eventually, during this period, Nigeria became a mono-cultural economy over depending on crude oil export for her foreign exchange (Efobi \& Osabuohien,2011).

Subasat (2002) reported that the protectionist policies of the developed countries and the increased substitution of synthetic for primary products in the technically advanced countries, the world oil market collapsed in mid1980s, resulting in a sharp drop in crude oil prices in the international markets.

Consequently, there was a significant decline in foreign exchange earnings from crude oil at a time when there was ever increasing demand for foreign exchange earnings by this import dependent economy. It became clear that crude oil export should not be looked upon to generate sustained growth (Adenuga, 2013). Therefore, additional sources of foreign exchange must be sought. All policy measures designed to improve the situation, including the stabilization measures in 1982 as well as the restrictive monetary policy and the stringent exchange control measures in 1984, proved ineffective. Consequently the Structural Adjustment Programme (SAP) was introduced in July 1986 by the federal government. (Onayemi \& Ishola,2009; Osuntogun \& Edordu,2001). One of the principal objectives of the programme was to diversify export from dependence on crude petroleum through the promotion of non-oil exports (Olorunshola, 1996). The non-oil-exports share of Nigeria's total export has remained under $10 \%$ for the most years since the introduction of SAP (Subasat, 2002; Ajakaiye \& Ayodele.2000). Lyakurwa (2001) reported that another characteristic of Nigeria's export trade is the continued reliance on developed countries as markets. The export promotion policy stance, which emphasizes the diversification of markets, appears not to be yielding desired results because exports to Organization of Economic Cooperation and Development (OECD) countries still dominate. What appears to be happening is a shift from exporting to European community to exporting to USA and Japan (Fliess \& Lesser,2010). This market concentration has been blamed, in part, for the countries misfortunes, as recessions in developed countries are usually fully transmitted to Nigeria. 
Negative effects from such shocks can be minimized by diversifying export markets especially since the level of economic activity is likely to vary across regions (Efobi \& Osabuohien, 2011; Olayiwola \& Okodua, 2009).

\section{2, Concept of Informal Non-Oil Export}

Non-oil export sector comprise those groups of economic activities which are outside the petroleum and gas industry or those not directly linked to them. It consists of sectors such as manufacturing, agriculture, telecommunication, service, finance, tourism, real estate, construction and health sector. Non-oil export in Nigeria are mainly primary products mostly agriculture products such as groundnut, cocoa, rubber, cotton, hides, skin, cattle, fabrics, corn, wheat, beans etc (Abogan, Akinola \& Baruwa, 2014).

Informal non-oil exporting are exporting activities that are not registered with government. They engage in unofficial business activities such as tax evasion, avoidance of labour laws and other government or institutional regulations (NEPC, 2012). Informal non-oil export in this study consists mainly of agricultural products, fabrics and some manufactured products in Nigeria which the exporters are not registered with government (Akintse, 2013). Note; this study excludes exportation of hard drugs such as Indian hemp, cocaine, heroine, human trafficking, prostitution etc.

\section{3, Informal Non-Oil Export in Nigeria and other West African Countries}

Informal export refers to trade transactions between residents and non-West Africans. Trade Hub Technical report (2006) in Africa and Ajumbo (2012) started observing and documenting the number of checkpoints on major West African transport corridors, and the bribes and delays truck drivers incurred at these check points. It was observed that a truck carrying export goods from Lome to Ouagadougou would get stopped a total of 17 times.

Bribes paid at roadblocks amounted to an average of US\$48 for exports per road block. Yet when compared to other countries in the region, both countries have relatively low level of bribes at road blocks suggesting that average bribes could be much higher in other parts of the region. The study estimated that delays caused by check point amounted to about four hours per trip. The number of checkpoints in West Africa is of great nuisance to exporters and transporters and significantly adds to the cost of doing business. Since transactional values in informal export average US\$100 to US\$1000, unnecessary checkpoints and bribes provide a great incentive for exporters to join the informal non-oil export sector (Ogalo, 2010.)

\section{4, Huge Revenue Loss as Nigeria Fails to Capture Non-oil Export Proceeds from 2009 to 2013}

Nigeria's inability to properly capture the value of non-oil exports moving to different markets in Africa, Europe and America in five years have cost the country US\$230 million in revenue that could have accrued as export duties to the federal government.

Between 2009 and 2013, the cumulative total of these un-captured non-oil export hit US\$46.19 billion, according to data from International Trade Centre (ITC), aggregated by the Nigeria Export Promotion Council (NEPC) (ITC, 2014).

On the other hand, information obtained from the Manufacturers Association of Nigeria Export Group (MANEG) showed that the federal government mandates each non-oil exporter to pay 0.5 percent duty on the value of the total non-oil exports to the Nigeria Customs Service (NCS). The 0.5 percent duty is often called Nigerian Export Supervision Scheme (NESS), according to MANEG. By implication, 0.5 percent duty on uncaptured US $\$ 46$ billion implies a revenue loss of US\$230 million.

Cobalt International Ltd is the Nigeria government appointed agency that inspects and calculates non-oil exports pre-shipment. On the other hand, the ITC is a subsidiary organization of the World Trade Organization (WTO) and the United Nations Conference on Trade and Development (UNCTAD), which provides trade technical assistance to 117 countries. Findings have revealed that while Cobalt obtained its data from the volumes of goods leaving the country, the ITC obtains data from import destination of countries, meaning that the latter obtains data on Nigeria's non-oil exports from countries where the exports move to.

Cobalt's 2009 data indicated that the country's non-oil exports data by the end of the year were US\$1.71 billion, but the ITC data revealed that actual non-oil exports were US\$ 6.56 billion. This leaves the country with an un-captured data of US $\$ 4.85$ billion, according to the ITC data.

Similarly, 2010 Cobalt's statistics revealed non-oil export value by the end of the year were US\$2.32 billion, but the ITC's showed the total exports as US\$4.82 billion, leaving the country with un-captured non-oil export of US $\$ 2.5$ billion.

In 2011, Cobalt non-oil exports calculation showed US\$2.79 billion, whereas the ITC's read US\$10.65 billion, meaning the value of the un-captured data was US\$ 7.86 billion.

In a related development, Cobalt's non-oil export in 2012 showed a decline to US $\$ 2.55$ billion, but the ITC's revealed an increase to US\$13.66 billion, leaving the country with an un-captured value of US\$11.11 billion.

In 2013, non-oil exports calculated by Cobalt indicated an increase to US\$2.973 billion, while the ITC's statistics showed a further increase to US\$22.850 billion, implying that un-captured data within the year reached 
a peak of US\$19.877 billion. Hence within these five years, the country has un-captured non-oil exports value of US\$46.19 billion.

Africa's biggest economy had failed to plug such and many other revenue loopholes, leading the country to incur so many wastes and resulting in graft and inability to meet financial and developmental obligations. Awolowo (2014) reported that the data indicated that 80 percent of non-oil export transactions were not recorded, accounting for the wide disparity in the official statistics in the country and those provided by the ITC. If the above data, especially the one from ITC is a true reflection of the activities in the sector, it suggest that a fraction of nonoil activities is being captured as an average of above 200 percent of the transactions are not recorded.

\section{5, Empirical Review}

According to Williams and Round (2008), in a study conducted in Moscow on the influence of informal export, $45 \%$ of the respondents reported involvement in informal export in order to satisfy their basic needs through generation of sufficient income to survive, $35 \%$ cited desire to own their own business while $20 \%$ reported overregulation. According to Taneja and Bimal (2016), in a study of determinants of informal export in India, the survey revealed that $69 \%$ of those studied cited over-regulation such as high duties and multiple taxes as strong incentives for informal export. The second most important factor for informal export to Pakistan identified by $58 \%$ of the respondents was unpatriotic government officials. The informal exporters operated their businesses with ease as a result of corrupt government officials. Also, 24\% of the respondents reported satisfaction of basic needs through income from informal export. In Ghana, a study conducted by Kwame and Williams opined that $51 \%$ of respondents reported basic survival as influence of informal export, 30\% reported corrupt government officials, while $19 \%$ cited over-regulation of formal export.

Throughout the literature on informal export and developing out of Maritz (2004), who divided informal exporters into those motivated by economic needs and those seeking self-realization, it has become popular to differentiate between necessity exporters pushed into informal export because of lack of alternatives and opportunity informal exporters doing so out of choice such as their wish for independence or desire to own a business (Harding et al, 2006, Zelizer, 2005, Reynolds et al, 2002). However, currently, especially in a western and post-socialist context, some scholars have begun to argue the inverse (Crick \& Chaundry,1997, Engman, 2008, Mwaniki, 2004). As Gerxhani (2004) asserts, many choose to participate in the informal export because they find more autonomy, flexible and desire to own a business than in the formal one.

Similarly, Snyder (2004) in her study of 50 informal entrepreneurs in New York asserts that $80 \%$ of the informal entrepreneurs she studied did so out of choice such as independence. Therefore, from this perspective the depiction of informal export as universally necessity-driven was replaced with a representation of them as universally doing so out of choice. Although this is a significant advance in understanding the determinants of informal export and one that transcends the universal hues of previous approaches, it continues to depict informal exporters as either satisfaction of basic needs or desire to own a business in other to be independent. They are viewed as separate categories constituted via their negation to each other. It has been argued that both satisfaction of basic needs and independence can be co-present in the rationale of individual informal exporters and also that the drivers underpinning informal exportation can change over time (Little, 2007, Williams \& Round, 2007)

\section{6, Costs and Benefits of Informality to Non-Oil Exporters}

Empirical research has tried to identify barriers to formalization. Ishengoma and Kappel (2006) survey evidence regarding the factors hindering the growth of informal enterprises. They distinguish between internal factors, such as limited human capital, lack of working capital, the utilization of obsolete technology and poor location, external factors, including limited access to financial services, limited access to business development services, a limited market, poor supply to economic infrastructure and burdensome government regulations. Based on a review of the literature and of donor experience, UNECA (2002) focuses on external factors and identifies seven categories of barrier to formalization from the entrepreneur's perspective:

a) Regulatory barriers b) Administrative barriers c) Fees and financial requirements

d) Corruption in public administration e) Socio-cultural attitudes

f) Lack of key business services and g) Criminality.

De Soto (1989) reported that the choice of whether to be formal or informal can be presented as a rational decision. Economic units weigh the costs and benefits that formalization entails and consider their particular institutional and resource constraints. The cost of formality can be divided into the costs of accessing the formal economy and those of remaining formal. A number of authors have applied the analytical framework proposed by De-Soto to a variety of different countries. Loayza (1996) surveys the existing literature and finds evidence of high access costs to legality in Latin America. He also finds evidence that remaining formal can be very costly too. Marginal tax rates on formal firms are typically very high in developing countries, given the narrow tax base. Finally, bureaucratic requirements also represent a significant cost of remaining formal. Loayza also surveys evidence on the costs of informality. He distinguishes between penalties when informal activity is detected and 
the cost of restricted access to government services. With regard to penalties, there is evidence to suggest that informal firms pay much higher bribes to corrupt government officials than formal firms and that they choose suboptimal sizes and capital to labour ratios to avoid detection.Golub, Mboye and Golubski (2019) compare the benefits of informality with the costs and risks associated with operating outside the rule of law, They conclude that, in the existing business environment, it can be rational for Africa entrepreneurs on the costs of informality, Hoffman and Melly (2015) came to the same conclusion.

\section{3, Methodology}

Descriptive survey research design was adopted for the study, while the sample size was determined using unknown population as stated below:

$$
\mathrm{n}=\underline{\mathrm{Py})(\mathrm{Pn})}
$$

Standard Error ${ }^{2}$

Generally, the following sequence and inputs are used in computing the sample size.

i. Survey respondents split 50/50 in response to dichotomous (Yes/No) questions. This help to identify the informal non-oil exporters from the formal operators during the pilot study.

ii. The desired level of confidence is $95 \%$ or 1.96 standard deviation from the mean or .05

Py $=$ Proportion responding "'Yes"'=50

Pn $=$ Proportion responding "'No"” $=50$

Standard Error is the acceptable amount of error/confidence interval. In the above case .05 (about 2 standard deviations or 0.0255102 )

$$
1 . \overline{96}
$$

Therefore the sample size is computed as follows:

$\begin{array}{lll}(\mathrm{Py})(\mathrm{Pn}) & =\frac{(.50) \mathrm{X}(.50)=}{.25} \\ \text { Standard Error }^{2} & (.05)^{2} \quad 0.0006507=384\end{array}$

Thus the sample size $=384$ respondents.

The sample procedure adopted in this study was convenience or judgemental sampling procedure. The target population was separated into different groups, in this study, geographical zones was used. Accordingly, research of this nature frequently uses convenience sampling procedure to ensure that the sample maintains the required precision and minimize error (Onoshchenko, 2012; Tull and Hawkins in Agbonifoh and Yomere, 1999). For this study, the researchers adopted the following procedure.

Divide the target population into homogenous subgroups; in our case the target population was divided into six geopolitical zones. From each political zone, the state with the highest incidence of informal non-oil export cross border operations was selected. The states selected were Katsina (North west), Adamawa (North east), Niger (North central), Ogun (South west), Abia (South east), Cross River (South south)

The instrument for this study was questionnaire, designed in a Likert Scale format which clearly captured variables identified and reviewed the study. Also, the questionnaire was designed with insight drawn from instruments of previous studies (Africa and Ajumbo, 2012; Ogalo, 2010) that measure similar constructs, however with adjustments to reflect Nigerian context.

The questionnaire instrument for this study was divided into two sections. Section A sought to elicit bio-data of the respondents, demographic variables namely: gender, age, marital status, ethnic background, religion, educational qualification, location of informal non-oil export (geographical zone). Section B sought to measure the constructs which relates to motives of informal non oil export with questions/items on a five point likert scale.

The instrument was validated by three professionals, in-order to determine the face validity of the instrument in respect to the research questions. To ascertain the content reliability of the instrument, a pilot study was conducted in Dawanau International Market Corridor, Kano State, Nigeria and Agbopon/Ebute-Ero ECOWAS Loading Point Lagos State, Nigeria. The two (2) states were purposively selected because they engage in huge informal non-oil exporting operations. The states were selected in-order to determine the reliability coefficient of the questionnaire and ascertain if the questionnaire was appropriate for the main study. A total of forty (40) respondents were selected for the pilot test (twenty respondents in each state), Copies of questionnaire were duly filled and returned. Data was analyzed with the Statistical Package for Social Sciences (Version 19), from the analysis of data, Cronbach Alpha reliability coefficient was observed at .863 , while .812 was obtained from Guttman Split-Half model. The individual respondents from the two (2) states who participated in the pilot study were not used for the main study.

The copies of the questionnaire were administered by the researchers. This method was to ensure that distribution and collection processes were systematic and controlled by the investigators..

The questionnaire used in the study was pre-coded for ease of analysis. The variables identified in the study together with their various dimensions were measured using a five point Likert scale which were pre-coded; 5 for 
strongly agree and 1 for strongly disagree. The two hypotheses formulated for the study were analysed using Kendall's Coefficient of Concordance. The data analysis was done with the aid of IBM SPSS Statistics 19 software.

\section{4, Data Analysis \\ Questionnaire Distribution and Collection}

A total of 384 copies of questionnaire were distributed to respondents in selected border markets and loading points in selected states within the six geo-political zones of Nigeria out of which 291 were returned as correctly filled, giving a response rate of $75.8 \%$ which was considered satisfactory and was informed by the method of distribution adopted (Onoshchenko, 2012).

\section{1, Data Analysis: General Linear Model}

The General Linear Model is the Multivariate Analysis of Variance (MANOVA) is for use when there are more than one independent variables that are related in some way or there should be some conceptual reason for considering them together. Two variables were used in this research to explore the "Determinants of Informal Non-Oil Exporting Behaviour in Nigeria" These variables are: satisfaction of basic needs and desperation to own a business. MANOVA performs and checks for significant difference on composite variables; and also provides the univariate results for each of the independent variables separately. MANOVA produces a number of results and we turn to explain them one after the other. The first output is the Box's Test of Equality of Covariance which shows whether the data violates the assumption of homogeneity of variance-covariance matrices. This also tests the null hypothesis that the observed covariance matrices of the independent variables are equal across groups. The value for Box's M is 182.749; F = 2.560 and the significance level is .000 hence we reject the null hypothesis that the observed covariance are equal across groups.

The next output is the multivariate statistics which test whether there are significant differences among the groups on a linear combination of the independent variables. Here there are a number of statistics to choose from: Wilks' Lambda, Hoteling's trace, and Pillai's Trace. The most commonly used is the Wilk's Lambda (Tabachnik \& Fidell, 2013). The three statistics however show similar results that are significant at .027 below the .05 margin hence there is significant difference among the variables. The implication of this is that the variables motivate informal non-oil export differently. This is shown in Table 4.1

The next box in the outputs of MANOVA is the Levene's Test of Equality of Error Variances which further lends credence to the multivariate statistics box above. The two variables show varying levels of significance with some below .05 margin and other far above it. This means that variables with significance level above .05 violate the equality of variance assumption. Because of this violation Tabachnik and Fidell (2013) recommend a conservative significance level of .01 rather than the conventional .05 level. The implication is that the variables motivates informal non-oil export but at varying levels as shown in Table 4.2.

A one-way between-groups multivariate analysis of variance was performed to investigate education differences in informal non-oil exporting. Two independent variables were used: satisfaction of basic needs and desperation to own a business. There was no statistically significant difference between the independent variables, $\mathrm{F}(6,98)=1.32$, sig. $=.166$; Wilk's Lambda $=.92$; partial eta $=.027$. When the results of the independent variables were considered separately, the only difference to reach a statistical significance using the Bonferroni and Scheffe post-hoc tests is the satisfaction of basic needs, $\mathrm{F}(3,25.4)=3.31$; sig. $=.021$; partial eta $=.033$.

\section{2, Hypotheses Testing}

The hypotheses formulated were tested using the Kendall's W Statistics as well as the Kendall's Coefficient of Concordance or measure of agreement among the respondents. The hypotheses are each restated before the test and the analysis.

Hypothesis One:

$\mathrm{H}_{1}$ : Satisfaction of basic needs promote involvement in informal non-oil export in Nigeria.

The first variable is the satisfaction of basic needs which was measured with five items the mean rankings of which are shown in the first box. From the results of the analysis, the Kendall's W statistics is .048, a Chi-Square value of 56.082 with a $\dot{\rho}$ (par) value of .000 which is less than the .01 margin of error/level of significance. Based on this we accept the hypothesis and conclude that satisfaction of basic needs promote involvement in informal non-oil export as shown in Table 4.4.

\section{Hypothesis Two:}

$\mathrm{H}_{2}$ : Desperation to own a business influence involvement in informal non-oil export in Nigeria.

The variable desire to own a business was measured with eight items and the mean rankings are shown. From the results of the analysis, the Kendall's W statistics is .084, a Chi-Square value of 171.036 with a $\rho$ (par) value of .000 which is less than the .01 margin of error/level of significance. Based on this we accept the hypothesis and conclude that desperation to own a business influence involvement in informal non-oil export as shown in Table 4.5. 


\section{Conclusions and Recommendations}

The following findings emanated from this study and they are as follows:

i. Satisfaction of basic needs promotes involvement in informal non-oil export in Nigeria;

ii. Desperation to own a business influence involvement in informal non-oil export in Nigeria

\section{Conclusions}

The first objective was to examine if satisfaction of basic needs promote involvement in informal non-oil export in Nigeria. The variable satisfaction of basic needs was measured with five items the mean rankings of which are shown in the first box. From the results of the analysis, the Kendall's W statistics is .048, a Chi-Square value of 56.082 with a $\dot{\rho}$ (par) value of .000 which is less than the .01 margin of error/level of significance. Based on this we conclude that satisfaction of basic needs promote involvement in informal non-oil export.

The second objective was to examine if desperation to own a business influence involvement in informal nonoil export in Nigeria. The variable was measured with eight items and the mean rankings are shown. From the results of the analysis, the Kendall's W statistics is .084, a Chi-Square value of 171.036 with a $\dot{\rho}$ (par) value of .000 which is less than the .01 margin of error/level of significance. Based on this we conclude that desperation to own a business influence involvement in informal non-oil export.

\section{Recommendations}

The study found that desperation to own a business promotes involvement in informal non-oil export in Nigeria. Exporting is business hence it is recommended that government should engage in capacity building to educate informal non-oil exporters to graduate to formal economy by registering their businesses and taking advantage of government incentives.

The study equally found that the desire to satisfy basic needs influence involvement in informal non-oil export in Nigeria. Based on this it was recommended that governments should create employment for the large number of unemployed and also create awareness on the need to shun opportunistic behaviours associated with informality. Importantly too, governments and policy makers should recognize that duality exists in all economies. The duality, formal and informal are usually associated with imbalances in the economy which are associated with the harsh economic realities of the time.

\section{References}

Abogan, O; Akinola,E and Baruwa,I (2014), Non-Oil export and economic growth in Nigeria (1980-2011), Journal of Research in Economics and International Finance Vol 3(1)

Adenugba, N (2013), Non-oil Export in the Economic Growth of Nigeria; A study of Agricultural and Mineral Resources, Journal of Economic Research, Vol

Afrika, J. K and Ajumbo, G (2012), Informal Cross Border Trade in Africa; Implications and Policy Recommendations; Vol 3 Issue [10]

Agbogun, M.R (2012), Encouraging Non-oil Export among Micro, Small and Medium Sized Entrepreneurs, Nigeria Export Promotion Council, Abuja.

Agbonifoh, B.A and Yomere, G.O (1999), Research Methodology in the Social Sciences and Education, Uniben Press, University of Benin city, Nigeria.

Ajakaiye, O. and Ayodele, S (2000), The Imperative for Energizing the Industrial Transformation in Nigeria, Bullion, 24(2), CBN Nigeria.Akintse, R (2013), Implications of Informal Exporting to Sub Saharan Africa, Research Journal of Economic Theory, 5(2)

Awolowo, O (2014), US\$230 million lost as Nigeria fails to capture US\$46 billion non-oil export, Businessday July 1.

Chambwer, M and Magregor, V. (2010), Premier for Development Professionals on the Importance of Informal Economy in Developing Economies, Presentation at WIEGO Network, Harvard Kenedy School, World Bank.

Crick, D and Chaudry, S (1997), Small Business Motives for Exporting, the Effect of Internationalization, Journal of Marketing Practice, Applied Marketing Science, (3)..

Efobi, U.R. and Osabuohien, E.S. (2011), Promotion of Non-Oil Export in Nigeria, Empirical Assessment of Agricultural Credit Guarantee Scheme Fund, Research Journal of Economic Theory, 3 (1)

Engman, M. (2008), Economic Impact of Trade Facilitation, OECD Trade Policy Working Paper, 21, South Africa

Gerxhani, K. (2004), Informal Sector in Developed and Less Developed Countries, A Literature Survey, Public Choice 120 (2)

Golub, S; Mboye, A; and Golubski, S. (2019), The Effects of Nigeria Closed Borders on Informal Trade with Benin; https://www.brookings.edu $>$ blog

Harding, R; Brooksbank, D; Hart, M; Jones - Evans, D; Levie, J and Walker, J (2006), Global Export Monitor United Kingdom, London Business School

Hoffman, L; and Melly, P (2015), Nigeria Booming Borders; The Drivers and Consequences of Unrecorded Trade, 
Chathan House Report, Royal Instituteof International Affairs, London.

International Labour Organization (ILO) (2018), Women and Men in Informal Economy; A Statistical Picture, Geneva: ILO

International Trade Center Statistics (2014), Online Businessday, July,1

Iweama, V. O. (2017), Determinants of Informal Non-Oil Exporting Behaviour: A Study of Cross-Border Traders in Selected Border Markets in Nigeria, Ph.D Dessertation, Department of Marketing, Nnamdi Azikiwe University, Awka-Nigeria

Iweama, V. O; Gorondutse, A. H; Nkamnebe, A. D. (2018), Theorisation of Informal Economy Towards A 4 Point Informal Non-Oil Export Construct Model in Nigeria; European Journal of Business Managemrent, Vol. 10 (27)

Little, P.O. (2007), Unofficial Cross Border Export in East Africa, Paper Presented at the FAO workshop on Staple Food Trade and Market Policy options for Promoting Development in East and Southern Africa, FAO Headquarters, Rome.

Lyakurwa, W.M. (2001), Trade Policy and Promotion in Sub-Saharan Africa, Special Paper 12, African Economic Research Consortium, Nairobi.

Maloney, W.F (2004), Informality Revisited, World Development, 32 (7).

Maritz, A. (2004), New Zealand Necessity Exporters, International Journal of Entrepreneurship and Small Business, 1.

Mwaniki, K. (2004), Crisis of Informal Export in Sub-Saharan Africa, Journal of African Economic Development, $16(3)$.

NEPC (2012), Informal Non - Oil Export in Nigeria, Technical Report of Nigeria Export Promotion Council, Abuja.

NEPC (2013), Identified Border Markets, Loading Points, Corridors and Associations of Informal Non - Oil Export in Nigeria, Technical Report of Nigeria Export Promotion Council, Abuja.

OECD (2004), Informal Employment and Promoting the Transition to a Salaried Economy, OECD Employment.

Ogalo, V (2010), Informal Cross-Border Trade in EAC, Implications for Regional Integration and Development, African Resource Centre Nairobi, Kenya.

Ojo, M.O. (1996), Diversification and Promotion of Nigeria's Energy Products, Bullion, 20 (2) CBN, Nigeria.

Olayiwola, K and Okodua, H. (2009), Foreign Direct Investment, Non - Oil Export and Economic Growth in Nigeria, A Causality Analysis, Proceedings for the $14^{\text {th }}$ Annual Conference on Econometric Society, Abuja.

Olorunshola, J. .(1996), Export - Led Growth in Economic Development, Lessons of Experience, Bullion, 20 (4), CBN.

Onayemi, S.O and Ishola, R.A (2009), Diversifying the Productive Base of Nigeria, an Econometric Approach to the Assessment of Non - Oil Export Promotion Strategies, International Research Journal of Finance and Economics, Issue 24.

Onoshchenko, O. (2012), Tackling the Informal Exporting in Ukraine, Thesis Submitted for the Degree of Doctor of Philosophy, Management School, University of Sheffield.

Osuntogun, A. and Edordu, C.C (2001), Diversifying Nigeria's Non - Oil Export to Non -Traditional Market, Research Paper 56.

Pinto, B. (1987), Nigeria During and After the Oil Boom, A Policy Comparison with Indonesia, The World Bank Economic Review, 1 (3)

Ramat, A (2011), identifying Informal Non-oil Export Markets and Loading Points in North western Nigeria, NEPC Bulletin .

Reynolds, P; Bygrave, E; and Hay, M (2002), Global Informal Export Monitor, 2002 Executive Monitor, London Business School.

Snyder, K. (2004), Routes to the informal economy in New York East Village: Crisis, Economics and identity, Sociological Perspectives, Vol. 47(2)

Spiegel, M. (1992), Synthesizing Evaluation Perspectives, Practices and Evidences, proceedings of the American Evaluation Association; 92 Evaluation, Tropical Interest Group, Seattle WA

Subasat, T. (2002), Does Export Promotion Increase Economic Growth?, Some Cross-Sector Evidence, Economic Policy Review, 2, Blackwell Publishing.

Tabachnik, B.G. and Fidell, L.S. (2013), Multivariate Statistics, $6^{\text {th }}$ Edition, California State University, htpps://www.pearsonhighered.com $>$ PG....

Taneja, N, and Bimal, S. (2016), India Informal Export with Pakistan, Workimg Paper 387, India council for Research on International Economic Relations

Teal, F. (1983), The Supply of Agricultural Output in Nigeria, Journal of Development Studies.

Williams, C.C and Round, J. (2007), Exporters and the Informal Economy, A Study of Ukraine's Hidden Enterprise Culture, Journal of Development Entrepreneurship,11 (2).

Williams, C.C and Round, J. (2008), Evaluating Informal Entrepreneurs Motives: Evidence from Moscow, 
www.emeraldinsight.com/1355.2554.htm

World Economic Forum (WEF) (2007), The Competitiveness Report, Daves, Switzerland.

Yusuf, A (2011), Identifying Informal Non-Oil Export Markets and loading points in North Western Nigeria, NEPC Bulletin

Zelizer, V.A. (2005), The Purchase of Intimacy, Princeton University, Princeton, NJ.

\section{Appendix}

Table 4.1: Multivariate Tests ${ }^{\mathrm{a}}$

\begin{tabular}{|ll|r|r|r|r|r|r|}
\hline Effect & Value & \multicolumn{1}{c|}{ F } & Hypothesis df & Error df & Sig. & Partial Eta Squared \\
\hline Intercept & Pillai's Trace & .952 & $929.681^{\mathrm{b}}$ & 6.000 & 282.000 & .000 & .952 \\
& Wilks' Lambda & .048 & $929.681^{\mathrm{b}}$ & 6.000 & 282.000 & .000 & .952 \\
& Hotelling's Trace & 19.780 & $929.681^{\mathrm{b}}$ & 6.000 & 282.000 & .000 & .952 \\
& Roy's Largest Root & 19.780 & $929.681^{\mathrm{b}}$ & 6.000 & 282.000 & .000 & .952 \\
\hline x6 & Pillai's Trace & .081 & 1.319 & 18.000 & 852.000 & .167 & .027 \\
\cline { 2 - 7 } & Wilks' Lambda & .920 & 1.321 & 18.000 & 798.102 & .166 & .027 \\
& Hotelling's Trace & .085 & 1.322 & 18.000 & 842.000 & .166 & .027 \\
& Roy's Largest Root & .053 & $2.521^{\mathrm{c}}$ & 6.000 & 284.000 & .022 & .051 \\
\hline
\end{tabular}

a. Design: Intercept $+\mathrm{x} 6$

b. Exact statistic

c. The statistic is an upper bound on $\mathrm{F}$ that yields a lower bound on the significance level.

Table 4.2: Levene's Test of Equality of Error Variances ${ }^{a}$

\begin{tabular}{|c|c|c|c|c|}
\hline & $\mathrm{F}$ & df1 & $\mathrm{df} 2$ & Sig. \\
\hline SoBN & 4.657 & 3 & 287 & .003 \\
\hline DOB & 1.230 & 3 & 287 & .299 \\
\hline
\end{tabular}

Tests the null hypothesis that the error variance of the dependent variable is equal across groups.

a. Design: Intercept $+x 6$

Table 4.3:

Kendall's W Test

\begin{tabular}{|l|r|}
\hline & \multicolumn{1}{c|}{ Manks Rank } \\
\hline SoBN 1 & 3.05 \\
SoBN 2 & 3.19 \\
SoBN 3 & 3.12 \\
SoBN 4 & 3.05 \\
SoBN 5 & 2.59 \\
\hline
\end{tabular}

Test Statistics

\begin{tabular}{|l|r|}
\hline $\mathrm{N}$ & 291 \\
Kendall's W & $\mathrm{a}$ \\
Chi-Square & .048 \\
$\mathrm{Df}$ & 56.082 \\
Asymp. Sig. & 4 \\
\hline
\end{tabular}

a. Kendall's Coefficient of Concordance 


\section{Hypothesis Test Summary}

\begin{tabular}{|c|c|c|c|c|}
\hline & Null Hypothesis & Test & Sig. & Decision \\
\hline 1 & $\begin{array}{l}\text { The distributions of SBoN } 1 \text {. SBol } \\
2 \text {. SBoN } 3 \text {. SBoN } 4 \text { and SBoN } 5 \\
\text { are the same. }\end{array}$ & $\begin{array}{l}\text { Related- } \\
\text { Samples } \\
\text { Nkendall's } \\
\text { Coefficient } \\
\text { of } \\
\text { Concordanc } \\
\text { e }\end{array}$ & .000 & $\begin{array}{l}\text { Reject the } \\
\text { null } \\
\text { hypothesis. }\end{array}$ \\
\hline
\end{tabular}

Asymptotic significances are displayed. The significance level is .05.

Table 4.4

Kendall's W Test

\begin{tabular}{|l|r|}
\hline & \multicolumn{1}{c|}{ Manks } \\
\hline & Mean Rank \\
\hline DOB 1 & 4.83 \\
DOB 2 & 5.23 \\
DOB 3 & 4.75 \\
DOB 4 & 4.54 \\
DOB 5 & 4.53 \\
DOB 6 & 4.53 \\
DOB 7 & 3.61 \\
DOB 8 & 3.98 \\
\hline
\end{tabular}

\begin{tabular}{|c|c|}
\hline \multicolumn{2}{|c|}{ Test Statistics } \\
\hline $\mathrm{N}$ & 291 \\
\hline Kendall's W $\mathrm{W}^{\mathrm{a}}$ & .084 \\
\hline Chi-Square & 171.036 \\
\hline Df & 7 \\
\hline Asymp. Sig. & .000 \\
\hline
\end{tabular}

Concordance

Hypothesis Test Summary

\begin{tabular}{|c|c|c|c|c|}
\hline & Null Hypothesis & Test & Sig. & Decision \\
\hline 1 & $\begin{array}{l}\text { The distributions of DOB } 1,00 B \\
\text { DOB } 3.00 B 4 . D 0 B 5 \text {. DOB } 6 \text {. } \\
\text { DOB } 7 \text { and DOB } 8 \text { are the same. }\end{array}$ & $\begin{array}{l}\text { Related- } \\
\text { Samples } \\
\text { 2.Kendall's } \\
\text { Coefficient } \\
\text { of } \\
\text { Concordanc } \\
\text { e }\end{array}$ & .000 & $\begin{array}{l}\text { Reject the } \\
\text { null } \\
\text { hypothesis. }\end{array}$ \\
\hline
\end{tabular}

Asymptotic significances are displayed. The significance level is .05 . 